\title{
CHALLENGES WITH IMPLEMENTING DATA WAREHOUSING OFFSHORE IN A FLAT WORLD: ISSUES FOR STUDY
}

\author{
Lisa A. T. Nelson, Robert Morris University, Itnst1@mail.rmu.edu
}

\begin{abstract}
Thomas Friedman, in his 2007 book, The World Is Flat: A Brief History of the $21^{\text {st }}$ Century (New York: Picador), discusses offshoring as a "flattener." As a business strategy enacted to attain high levels of competency while reducing cost, offshoring is not a new idea, especially in information technology. The strategy of offshoring data warehousing and business intelligence (BI), however, is relatively new. In fact, there is little industry and trade literature on the topic, and virtually is no research available in the management, decision sciences, and information systems academic literature. This dearth of research persists despite recognition that business intelligence and data warehousing activities are gaining credence as competitive differentiators for companies. This paper highlights this research void, offering a review of the very limited literature available on the topic. Additionally, the paper sketches a picture of the challenges and risks companies face when deploying their data warehousing offshore; these challenges involve complexity, cultural communication, and data security. A discussion of outsourcing and offshoring in the context of Friedman's "flat world" illustrates the social ramifications of offshoring and reinforces the call for increased research in the field.
\end{abstract}

Keywords: Data warehousing, business intelligence, offshoring, IT competencies, social ramifications of offshoring, "flat world", Thomas Friedman

\section{INTRODUCTION}

Thomas Friedman recounts his revelation about increasing globalization and technology's role in it in The World Is Flat: A Brief History of the $21^{\text {st }}$ Century (New York: Picador, 2007). Infosys' CEO Nandan Nilekani, during a visit with Friedman on Infosys' Bangalore, India, campus, remarked, " 'The playing field is being leveled.' " Friedman interpreted this as, "My God, he's telling me the world is flat!" [12].

In his book, Friedman discusses ten major "flatteners," some of which, arguably, are more significant than others. Two of these flatteners are outsourcing and offshoring. The basic business premise of outsourcing is competency: If a company is incompetent in performing a particular function, then it will transfer responsibility for performing that function to an organization that specializes in it. As business strategies enacted to attain high levels of competency while reducing cost, outsourcing and offshoring are not new ideas, especially in information technology. In fact, according to a 2006 report published by the United States Government Accountability Office, the majority of offshoring has occurred in information technology, particularly in software development and customer service $[17,30]$.

There is a wealth of research in both academia and in industry regarding offshoring IT functions for cost and labor efficiency [7, 8, 17]. The strategy of offshoring data warehousing and business intelligence (BI), however, is relatively new. In fact, there is little industry and trade literature on the topic [17]; furthermore, there virtually is no research available in the management, decision sciences, and information systems academic literature [17]. This dearth of research persists despite evidence that business intelligence and data warehousing activities are gaining credence as competitive differentiators for companies [19].

Responding to the gap in the literature on offshore data warehousing, this paper reviews the limited literature available on this particular subject, while sketching a picture of the challenges and risks companies face when deploying their data warehousing offshore. Readers should note that many people confuse outsourcing and offshoring, saying "outsourcing" when they really mean "offshoring." Friedman is clear in delineating that "[o]ffshoring... is when a company takes one of its factories that it is operating in Canton, Ohio, and moves the whole factory offshore to Canton, China" [12].

In the case of offshoring, companies are seeking economic advantages to acquire relatively inexpensive labor and expertise in to Eastern Europe, the Pacific Rim, Latin America, and India [3] to perform particular competencies [9], to reduce costs, and to improve their competitive advantage. What separates offshoring from other like initiatives is its increasing influence on global socio-economic issues. 
Friedman's comprehensive, thoughtful view of how geographical and social boundaries are blurred by outsourcing and offshoring assists business intelligence professionals and researchers in this regard. This paper concludes with a discussion of outsourcing and offshoring in the context of Friedman's "flat world" to illustrate the social ramifications of offshoring. These ramifications clarify the call for increased research of the practice of deploying business intelligence offshore.

\section{CHALLENGES FOR OFFSHORE DATA WAREHOUSING}

A major challenge involved with offshoring IT is deciding what aspects of IT to deploy offshore and where to deploy them [28]. Traditionally, IT "activities like rehabilitation and maintenance of legacy systems, facilities management, help desk support, eCommerce applications, and ERP installations" have been implemented offshore [1]. Offshore implementation of data warehousing and other business intelligence activities are slowly emerging as new trend in recent years, inspiring IT industry analysts to examine where data warehousing fits in the flat world [2]. Industry experts appear split in their opinions as to the feasibility and desirability of implementing data warehousing offshore; warnings persist amidst recognition of the economic sense.

As is true when offshoring any IT competency, companies, in order to reduce risks, must thoroughly prepare and exercise caution when offshoring data warehousing $[1,28]$. This particularly is true for complex application development work; "the more complicated the application development work, the more complicated the risks in most cases" [9].

Risks and challenges companies face when offshoring any IT activity, including data warehousing, include the physical distance; the cultural, legal, and political climate; increasing management complexity; loss of control over operations and intellectual property; data security and integrity; and rejection of the company by the local community $[1,10,27,28]$. Of these several challenges, I will address the three most commonly cited by industry experts as the most daunting: 1) management complexity, 2) the cultural, legal, and political climate, and 3) data security. Failure on the part of management to properly prepare for these challenges may culminate in the erosion of overall work quality.

Volume X, No. 2, 2009

\section{Complexity}

Traditionally, aspects of IT deployed offshore involve data processing, not management of the data itself. Call center processes, for example, may be standardized across industries and companies. There is some rigidity involved in the implementation. The data environment (comprising the situations in which end users use data), in contrast, is too fluid [15].

Critics of offshore data warehousing (i.e., global data warehousing), therefore, assert that the data warehouse is too complex and not entirely suited for offshore implementation $[10,15]$. "[T]he fact that a data warehouse is an essential architectural component" [15] of an organization makes offshoring a data warehouse a risky endeavor. Additionally, "data warehouses are never complete"; it is essential to continually update the data warehouse to adapt to the growth or changing needs of the business [15].

CIOs do not have the time to constantly oversee offshoring most IT projects, let alone offshore projects surrounding complex essential architecture [25]. The physical distance involved with offshoring only complicates challenges imposed by the complexity of the data warehousing effort; maintaining a high level of interaction between domestic and off-shore sites is difficult across several time zones [24].

\section{Cultural Communication}

Technical complexity and issues aside, "nontechnical" issues involving cultural communication complicate implementing data warehousing and business intelligence activities offshore. Dine and Pohl [10], in their analysis of Sunrise Medical's global data warehousing (GDW) project, identify work schedules and norms, language, and currency differences as potential obstacles to the success of the project. Varying cultural work norms and schedules and language interfered with the level of intensive communication and interaction required for the success of the project. Language and currency differences represented issues for both cultural and data programming.

Sunrise Medical, when implementing GDW in Europe, considered the work norms and schedules of their host countries in planning the project. Meetings and teleconferences, for instance, were held in the afternoon for the European host country, as is common [10]. Also, time off and vacations needed to 
be factored into project planning; "the U. S. only averages less than 14 official days of vacation and holiday time," compared with more than 30 days common in European countries [10].

A potential language barrier may threaten maintaining an intense level of interaction between domestic and offshore locations. "Since English is often a second or third language for [offshore data warehousing] team members, communication must be very detailed, specific, and comprehensive" [1; see also 10]. Sunrise Medical's data warehousing offshore implementation effort was led by a U.S.based team. E-mail and voice mail were used to overcome the time zone difference; accuracy in communications was lost, however, in a sea of idioms, slang, and acronyms. Additional time was spent clarifying communication, thus impeding efficiency.

The GDW implementation team determined English to be the primary language for the GDW project; however, this "did not mean that we would not be translating all source data into English" [10]. Some words in certain languages do not translate to English. Several adaptations needed to be made, including using ISO (International Standardization Organization) codes where necessary for local codes and currency.

Daily currency exchange rates also were added to Sunrise Medical's GDW via a source service especially selected for the project. The GDW stored U. S. dollar data, as well as sales data in local currencies. The exchange rates were downloaded daily, "allow[ing] the GDW to also calculate a variety of average exchange rates that users desired for reporting" (paragraph 22).

\section{Data Security}

When considering implementing any IT function offshore, it is critical to engage an offshore provider that knows what they are doing $[15,28]$. This especially is true for data warehousing and business intelligence. The question here is whether offshore providers are up to the task and can be trusted with a company's sensitive data. Data security and privacy is a risk related to the complexity of a data warehousing effort. "It is fair to say that offshore developers have not reached the levels of sophistication to deal with the architectural considerations of the design and development of a data warehouse" [15].

Volume X, No. 2, 2009
Data security and privacy, according to Bill Inmon, is a strategic imperative that should not be jeopardized by attempts to move data warehouses offshore: "Data warehouses contain corporations' bedrock data. Allowing that data to get out of control is taking a very serious risk, one where the very core business of the corporation may be compromised. Indeed, in some cases it may actually be illegal to build a data warehouse offshore because of the nature and content of the data." [15]

Examples of laws enacted to protect data privacy include the Gramm-Leach-Bliley Act of 1999 for financial data and the Health Insurance Portability and Accountability Act (HIPAA) of 1996 for health insurance and medical data [26]. There are other international laws and export regulations on the books that limit the offshoring effort of certain companies, such as defense contractors Raytheon, Boeing, and Lockheed Martin. Nevertheless, companies increasingly walk the line between striving for cost efficiency and global collaboration and risking the exposure of their data.

\section{CURRENT INDUSTRY ATTITUDES TOWARD OFFSHORE DATA WAREHOUSING}

Business intelligence professionals' enthusiasm toward offshore implementation of data warehousing is tempered by their awareness of the risks, challenges, and complexity involved in the effort. Yet, according to business intelligence experts Nenad Jukic and Creighton Lang [17], "proven knowledge and methodologies about offshore development models" are emerging, inspiring business intelligence professionals to examine the possibilities of offshoring data warehousing and business intelligence activities [17].

Outcomes from an IT industry study conducted by Jukic and Lang suggest that some of the challenges, namely physical distance and cultural communications, indeed, are surmountable. The authors interviewed and surveyed over 40 "mid- and high-level data warehousing professionals involved in BI projects at large U.S.-based corporations, representing a variety of industries" [17] in order to isolate their opinions about offshoring business intelligence and data warehousing. At the time of the study, the majority of the managers participating in the study were not engaged in offshoring BI activities.

In fact, a prevailing opinion among the respondents in Jukic and Lang's study viewed offshoring BI activities to be "inefficient" [17]. Specifically with 
regard to extracting, transforming, and loading (ETL), 65 percent of the respondents claimed that offshoring ETL is "realistic" [17]; however, costs involved with rework due to misinterpretation of rules and requirements [17] and suffering quality and offset any initial cost benefits. Yet the "structured nature of ETL allows for offshore development of some tasks," although the very clarity and precision of communication and requirements is critical for success [17].

Clear communication and on-site team involvement also were cited by respondents as critical to the success of offshoring maintenance and support tasks and end-user development. Fifty-three percent of respondents held the view that maintenance and support could be implemented offshore; system monitoring, for example, could be accomplished remotely from offshore [17]. Less than half of the survey respondents believed that development of end-user applications (including reporting) could be efficiently done offshore; the caveat issued by respondents is that strict requirements would need to be defined onshore [17; see also 10].

Jukic and Lang's conclusions indicated that the attitude among business intelligence professionals was measured and cautious; regardless, data warehousing implementation offshore is in the nascent stages. When a company does face the decision to implement data warehousing and other business intelligence activities offshore, they can "leverage lessons learned from non-BI experiences while integrating offshore delivery models into the unique methodologies often employed by the data warehousing profession" [17].

\section{OFFSHORING DATA WAREHOUSING IN A FLAT BUT FLOUNDERING ECONOMY}

Today, IT consultancy firms advertise their ability to enable companies to innovate and to compete in a globalized, "flat" world. Infosys, Nandan Nilekani's company, touts its "[p]ractitioners and experts [that] help you manage change, innovate and compete effectively in the Flat World" [14]. The FlatWorld Group, a network of IT offshoring partners in India, promotes the capability to specialize in a variety of IT functions, including business intelligence and data warehousing [13].

The flatness of the global economy, combined with the current economic downtown, may sour some IT decision makers from attempting any innovative moves with offshoring such complex, critical architecture. Yet current economic conditions also may tempt others to rush the learning curve with offshoring data warehousing. Gartner analyst Linda Cohen observes, "Whenever there's a downturn people outsource more, not less... Organizations want to take costs out wherever they can. CFOs are pounding on their CIOs to just outsource it, just offshore it" [23]. Inmon's warnings about offshoring data warehousing resonate, however, when we see IT decision makers making hasty decisions that may haunt them in the long term.

\section{SOCIAL IMPLICATIONS OF OFFSHORING IN A FLAT-WORLD ENVIRONMENT}

This paper introduced offshoring as one of Thomas Friedman's most significant flatteners because of its enormous potential socio-economic and political impact. This impact, along with the aforementioned organizational challenges and risks, foreshadows potential socio-economic and political issues with deploying business intelligence offshore. Future research on offshore data warehousing and business intelligence, therefore, should focus on social implications of the practice.

Global poverty, according to Friedman, is just one major example of a global socio-economic issue influenced by offshoring. Friedman frequently addresses offshoring's positive effects on alleviating poverty in the third world while simultaneously boosting the economy at home [12]. He posits that "[p]oor people grow out of poverty when their governments create an environment in which educated workers and capitalists have the physical and legal infrastructure to...subject their people to at least some competition from beyond" [12]. Offshoring partnerships do this by perpetuating free trade [12], arguably the most conducive environment.

Poorer, third-world nations, perhaps the biggest beneficiaries of offshoring to date, stand to experience severe consequences of continued practice. The jury is still out as to how long the recent economic resurgence in the third world will last. In India, for instance, "much poverty still remains," despite "an unprecedented average growth rate of over 8 percent" since 2003 [21]. Additionally, the income inequality between the rich and the poor (termed by some economists as "first-world India" versus "third-world India") is increasing [16]. In China, poverty has declined from $64 \%$ to $10 \%$ between 1960 and 2004; however, the inequality gap also is ever widening [11]. These disparities in India and China largely are the result of entrenched class and caste systems, which are exacerbated by offshoring [20; see also 16]. According to the 2007 
OECD Employment Outlook, offshoring "may be one of the driving forces behind the increase in the vulnerability of jobs and wages" in Brazil, Russia, India, and China [22].

Evidence of the negative effects of offshoring in emerging markets aside, the larger part of the "current debate about offshoring focuses on its impact on U.S. jobs" [4]. Increasingly, dyed-in-thewool capitalists and free-trade advocates warn that "offshoring may be the biggest political issue in economics for a generation" [5]. Offshoring has exploded beyond exporting lower-skill services (e.g., customer service calls) to "radiology, architecture, and engineering" [5], endangering millions more Western, first-world, white-collar jobs [6, 18, 27, 29]. The Center for American Progress [6] has appealed to Congress to "engage in a serious dialogue on these questions and consider a range of potential public policy responses to address not only the pain and dislocation that offshoring creates."

\section{REFERENCES}

1. Agosta, L. (2004, July 12). Making offshore data warehousing services work. Cambridge, MA: Forrester Research. Retrieved February 18, 2009, from

http://www.forrester.com/Research/Document/E xcerpt/0,7211,34990,00.html

2. Agosta, L. (2006, March 1). Data warehousing in a flat world: Trends for 2006. Information Management. Retrieved February 18, 2009, from http://www.information-

management.com/issues/20060301/10492341.html

3. Anderson, T. (2007, October 16). Seven reasons why outsourcing to India is good for your business. CIO.Retrieved February 12, 2009, from http://www.cio.com/article/146451

4. Baily, M. N. \& Farrell, D. (2004, July). Exploding the myths of offshoring. The McKinsey Quarterly. Retrieved February 19, 2009, from

http://www.mckinseyquarterly.com/Exploding_t he_myths_of_offshoring_1453

5. Blinder, A. S. (2007, May 6). Free trade's great, but offshoring rattles me. Washington Post, B04.

Retrieved February 17, 2009, from http://www.washingtonpost.com

6. Center for American Progress. (2004). The impact of offshoring on the U.S. economy: Policy perspectives. Retrieved February 19, 2009, from http://www.americanprogress.org/issues/kfiles/b 81290.html
7. Chen, C. C., Land, J., \& Fox, J. B. (2008, November). The strategic agility of information systems outsourcing. Paper presented at the Decision Sciences Institute's 2008 Annual Meeting [Information Systems track],

Baltimore, Maryland. Retrieved February 12, 2009, from

http://www.decisionsciences.org/Proceedings/DS I2008/docs/410-4952.pdf

8. Clott, C. B. (2004). Perspectives on global outsourcing and the changing nature of work. Business and Society Review, 109(2), 153-170. Retrieved February 12, 2009, from EBSCO Business Source Premier database.

9. Cohen, R. (2006, November 9). Effective strategies for offshoring business intelligence application development. Information Management. Retrieved February 12, 2009, from http://www.informationmanagement.com/news/1068645-1.html

10. Dine, S. \& Pohl, M. E. (2002). Going global with data warehousing: Challenges to consider with multi-country data warehousing. Journal of Data Warehousing, 7(2), 10-14.

11. Dollar, D. (2007, June 18). China: Poverty down, inequality up. Message posted to the New Economist,

http://www.neweconomist.blogs.com/new_econ omist/poverty_and_inequality/index.html

12. Friedman, T. L. (2007). The world is flat: A brief history of the $21^{\text {st }}$ century ( $3^{\text {rd }}$ ed.). New York: Picador.

13. FlatWorld Group. (2006). Smart outsourcing: The "RENT" model. Retrieved February 18, 2009, from http://theflatworldgroup.com/outsourcing.aspx

14. Infosys Technologies, Ltd. (2009). Flat world. Retrieved February 18, 2009, from http://www.infosys.com/flatworld/business/default.asp

15. Inmon, B. (2004, November 1). Straight talk: Data warehousing and offshore development. Information Management. Retrieved February 18, 2009, from http://www.informationmanagement.com/issues/20041101/10124031.html

16. Johnson, J. (2007). Inequality: A threat to India's economic boom. Financial Times. Retrieved February 6, 2008, from http://www.ft.com

17. Jukic, N. \& Lang, C. (2004). Using offshore resources to develop and support data warehousing applications. Business Intelligence Journal, 9(3), n. p. Retrieved February 12, 2009, from http://wwwtdwi.org/research/display.aspx?ID=7 205 
18. Koch, C. (2003, September 1). The politics behind offshore outsourcing. CIO [Electronic version]. Retrieved February 12, 2009, from http://www.cio.com

19. Kumar, A. \& Janakiraman, M. (2008). Cognizant Technology Solutions: Growth and transformation of its data warehousing and business intelligence division. Journal of Information Technology Case and Application Research, 10(3), 56-83. Retrieved February 12, 2009, from ABI/INFORM Global database.

20. Michel, R. (2004). Sorting out offshoring versus outsourcing. MSI, 22(1), 2. Retrieved February 6, 2008, from ABI/INFORM database.

21. Nayar, B. R. (2007). India's globalization: Evaluating the economic impact [Monograph]. Excerpt in T. L. Friedman, The world is flat: A brief history of the $21^{\text {st }}$ century $\left(3^{\text {rd }}\right.$ ed.) (434437). New York: Picador.

22. Organisation for Economic Co-operation and Development (OECD). (2007). Editorial: Addressing the globalisation paradox. OECD Employment Outlook. Retrieved February 4, 2008, from http://www.oecd.org/dataoecd/29/26/38749245.p df

23. Overby, S. (2008, December 18). Offshoring and outsourcing in 2009: What does the future hold for the IT services industry. CIO. Retrieved February 19, 2009, from http://www.cio.com/article/471713

24. Overby, S. (2007, October 16). Eight reasons why outsourcing to India could hurt your business. CIO. Retrieved February 12, 2009, from http://www.cio.com /article/146450

25. Overby, S. (2005, November 15). Working with offshore partners requires $\mathrm{CIO}$ oversight. CIO. Retrieved February 12, 2009, from http://www.cio.com/article/14296

26. Overby, S. (2004, January 15). Offshore outsourcing: How to safeguard your data in a dangerous world. CIO. Retrieved February 12, 2009, from http://www.cio.com/article/32057

27. Overby, S. (2003, September 1). The hidden costs of offshore outsourcing. CIO. Retrieved February 12, 2009, from http://www.cio.com/article/29654

28. Perkins, B. (2003). Selecting the right offshore vehicle. Computerworld, 37(37), 46. Retrieved February 12, 2009, from EBSCO Business Source Complete database.

29. Thibodeau, P. (2008, August 29). Offshore outsourcing impacts IT workers hardest, survey finds. CIO. Retrieved February 12, 2009, from http://www.cio.com
30. United States Government Accountability Office. (2006, May). Offshoring in six human services Programs (originally published March 2006). Report to Congressional Committees, GAO-06-342. 